\title{
MENDIALOGKAN LEGITIMASI NIKAH SIRRI DALAM RANAH TEOLOGIS DAN YURIDIS (Interpretasi Hadits Larangan Nikah Sirri Dalam Perspektif Antropologi)
}

\author{
Moh. Nailul Muna \\ UIN Sunan Kalijaga \\ m.nailulmuna7@gmail.com
}

\begin{abstract}
Abstrak
Dalam memperbincangkan pernikahan, tidak bisa lepas dari dua ranah yang melikupinya yakni, keyakinan dan hukum. Permasalahan nikah sirri adalah permasalahan yang sampai saat ini masih menarik untuk diperbincangkan karena masih maraknya praktek ini. hadits yang merupakan sumber hukum Islam kedua telah melarang secara jelas praktek nikah yang tidak dihadiri oleh wali, meski al-Qur'an tidak menyinggung hal ini namun dalil-dalil yuridis telah menguatkan larangan nikah sirri karena akan mengakibatkan ketidak-jelasan hubungan suami istri, selain itu keengganan untuk mencatatkan pernikahan yang menjadi faktor utama pelarangan nikah sirri. Namun dalam perspektif antropologi, nikah sirri tidak selamanya dilarang dengan mempertimbangkan eksistensi hadits serta keadaan sosiologi yang ada. Tulisan ini bertujuan supaya memberikan new meanings dalam memahami nikah sirri dengan menggunakan perspektif antropologi.
\end{abstract}

Keywords: Nikah Sirri, Hadits dan Antropologi

\section{Pendahuluan}

Hadits sebagai ajaran Islam senantiasa dijadikan sebagai pedoman dalam kehidupan ummat Islam. ${ }^{1}$ Hal ini menjadi penting karena di dalamnya menjelaskan tentang tuntunan dan pengajaran yang benar melalui sosok Nabi Muhammad saw. As-Sunnah (hadits Nabi saw.) merupakan penafsiran Al-Qur'an dalam praktek atau penerapan ajaran Islam secara faktual dan

${ }^{1}$ Muhammad Alfatih Suryadilaga, "Syarah Hadits Shahih Bukhari dan Muslim dalam Komik", Esensia, Vol. 16, No. 2, Oktober 2015. 
ideal. ${ }^{2}$ Hal ini tentu menjadikan nilai hadits akan terinternalisasi dalam setiap individu muslim, salah satu praktek yang dianggap mendapatkan legitimasi dari agama adalah nikah sirri. Hal ini disebabkan karena tidak adanya keterangan tentang larangan nikah sirri yang dituliskan secara eksplisit dalam al-Qur'an.

Dalam hal ini, penelitian hadits merupakan suatu keniscayaan dalam kehidupan umat manusia saat ini. Dimensi ajaran agama Islam yang dibawa Rasulullah saw. mengharuskan untuk mendapatkan informasi yang benar dan akurat. Lebih lanjut Alfatih mengkritik penelitian hadits yang hanya memperhatikan otentisitas hadits, baik dari segi sanad dan matan, hal tersebut merupakan sesuatu yang mudah. ${ }^{3}$ Terlebih saat ini sudah banyak ditemukan aplikasi-aplikasi yang memudahkan orang untuk mencari keotentikan hadits secara instan. Oleh karena itu, seharusnya penelitian hadits harus lebih luas yang mengkaitkannya dengan masalah kekinian, termasuk di dalamnya masalah nikah sirri.

Dari perkembangan-perkembangan yang terjadi, hadits sebagai sumber kedua dalam Islam masih tetap eksis, hal ini dibuktikan dengan semakin maraknya re-building atas ajaran-ajaran hadits melalui banyak media, seperti: Pengajaran hadits yang mulai diperkenalkan dimedia massa hal ini dapat diketahui dengan adanya kajian yang dilakukan oleh Dr. Lutfi Fathullah, MA yang lebih mengedepankan pemahaman hadits yang sangat diperlukan oleh masyarakat. ${ }^{4}$ Kemudian adanya pengajaran hadits melalui media visualisasi, tepatnya dalam karya komik, seperti yang dilakukan oleh Veby Surya Wibawa yang membuat komik "99 Pesan Nabi: Komik Hadis Bukhari Muslim (Edisi lengkap). ${ }^{5}$

Antropologi adalah salah satu disiplin ilmu dari cabang ilmu pengetahuan sosial yang memfokuskan kajiannya kepada manusia. Objek dari antropologi adalah manusia di dalam masyarakat suku bangsa, kebudayaan dan perilakunya. Jika budaya tersebut dikaitkan dengan agama, maka agama yang dipelajari adalah agama sebagai sebuah fenomena budaya,

2 Yusuf al-Qardhawi, Bagaimana Memahami Hadits Nabi saw., terj. Muhammad al-Baqir (Bandung: Mizan, 1997), hlm.17

3 Alfatih Suryadilaga, Aplikasi penelitian Hadits dari Teks ke Konteks (Yogyakarta: Kalimedia, 2016), hlm.2.

4 Muhammad Alfatih Suryadilaaga, "Kajian Hadits di Media", Jurnal Esensia Vol. 15 No. 2 September 2015, hlm. 203.

${ }^{5}$ Muhammad Alfatih Suryadilaga, "Syarah Hadits Shahih Bukhari dan Muslim dalam Komik". 
bukan ajaran agama yang datang dengan perantara seorang Rasul dan sebagainya. ${ }^{6}$

Kajian tentang antropologi dan hadits merupakan dua disiplin ilmu yang berbeda, namun kajian tentang antropologi akan menarik tatkala dilakukan dalam kajian hadits yang sejauh masih minim multi perspektif dalam memahami makna-maknanya. Oleh karena itu, kajian ini akan memfokuskan terhadap permasalahan nikah sirri berdasarkan hadits Nabi serta perundang-undangan kenegaraan yang dilihat dalam perspektif antropologi, hal ini diharapkan akan menghasilkan suatu hasil yang baru dalam melihat hukum nikah sirri melalui perspektif yang berbeda.

\section{Nikah Sirri}

Nikah sirri merupakan istilah yang sering didengar di telinga masyarakat Indonesia, terlepas dari segala polemik yang melikupinya, sejatinya istilah nikah sirri dapat bermacam-macam seperti nikah misyar dan nikah urfi sebagaimana yang terjadi di Mesir. Untuk mengungkap makna yang mendekati kebenaran, maka perlu tinjauan sisi kebahasaan dari perkataan nikah sirri. ${ }^{7}$

Kata Sirri sendiri berasal dari bahasa arab yaitu sirrun yang artinya rahasia. Istilah assaru dapat diartikan rahasia, atau asarrayu yang artinya secara rahasia atau sembunyi-sembunyi, sedangkan sirran berarti diamdiam. $^{8} \quad$ Di dalam literatur fikih, Islam tidak mengenal yang namanya nikah sirri, namun dalam sejarah Islam, istilah nikah sirri muncul ketika zaman khalifah Umar bin hattab ra. ketika beliau diberitahu bahwa telah terjadi perkawinan yang tidak dihadiri oleh saksi yang memadai. Umar bin Khattab berkata: "Ini adalah nikah sirri dan aku tidak membolehkannya. Dan sekiranya aku datang pasti aku rajam". Pengertian kawin sirri tersebut dikarenakan adanya kasus pernikahan yang tidak menghadirkan saksi yang sesuai dengan ketentuan. Dengan demikian, asal penggunaan nikah sirri adalah nikah yang tidak dihadiri oleh saksi. ${ }^{9} \quad$ Sedangkan saksi sendiri merupakan bagian dari rukun sebuah pernikahan. Tanpa adanya saksi, maka pernikahan menjadi tidak sah.

${ }^{6}$ Alfatih Suryadilaga, Metodologi Syarah Hadits (Yogyakarta: Kalimedia, 2017), hlm. 81.

7 Alfatih Suryadilaga, "Nikah Sirri dalam Perbincangan Media Massa", Musawa, Vol 12 No. 1 Januari 2013, hlm. 106.

${ }^{8}$ A. W. Kamus al-Muanawwir Arab Indonesia Terlengkap (Surabaya: Pustaka Progressif, 1997), hlm. 431.

9 Alfatih Suryadilaga, "Nikah Sirri dalam Perbincangan Media Massa” ... hlm.106. 


\section{Nikah sirri dalam ranah keyakinan}

Hukum nikah sirri memang tidak tertulis secara tersirat maupun tersurat dalam al-Qur'an, kasus ini biasanya dikaitkan dengan kurangnya prasarat sahnya nikah yakni: Pertama, adanya calon suami dan istri. Kedua, adanya wali pengantin perempuan. Ketiga, adanya saksi-saksi yang adil. Keempat, adanya mahar. Kelima, ljab qabul. Namun, dalam nikah sirri hilangnya rukun yang ketiga, dan kemungkinan tidak adanya wali juga.

Perlu digaris-bawahi terkait nikah sirri (sembunyi-semunyi) di sini, yakni nikah dengan ketidak-adaan wali, berdasarkan hadits Nabi saw. :

\section{لا نكاح إلا بولي :}

"Tidak ada pernikahan tanpa wali"

Kemudian jika pernikahan sirri telah terjadi, maka hukumnya adalah hendaknya mereka dipisahkan, suami tetap memberikan mahar jika menyentuhnya, dan setelah dipisah, ia menikahinya dengan akad dan mahar jika walinya merelakan dengannya. ${ }^{10}$ Adapun diantara dalil hujjah yang bisa digunakan untuk merujuk pelarangan nikah sirri :

Berdasarkan hadits dalam Sunan Abu Dawud mengenai ketidak-adaan izin Wali dalam pernikahan. ${ }^{11}$ :

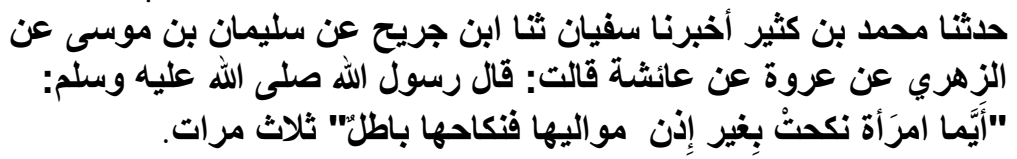

"Telah menceritakan kepada kami Muhammad bin Katsir, telah mengabarkan kepada kami Sufyan, telah mengabarkan kepada kami Ibnu Juraij, dari Sulaiman bin Musa dari Az-Zuhri dari Urwa, dari Aisyah, ia berkata: Rasulullah saw, bersabda: "Setiap wanita yang menikah tanpa seizin walinya, maka pernikahannya adalah batal". Beliau mengucapkannya sebanyak tiga kali".

Memang dalam memahami hadits Nabi, tidak bisa dipahami dengan sedemikian rupa tanpa melalui usaha takhrij hadits dan juga kritik (naqd) matan yang melikupi 3 hal. Pertama, meneliti matan dengan melihat kualitas sanadnya. Kedua, meneliti susunan lafal matan yang semakna. Ketiga, meneliti kandungan matan. ${ }^{12}$ Oleh karena itu, paling tidak melakukan takhrij untuk menunjukkan otentisitas hadits-hadits yang melarang praktek nikah sirri. Hadits yang pertama diriwayatkan oleh 7 perawi dan kesemuanya

10 Ali Yusuf As-Subki, Fikih Keluarga"pedoman berkeluarga dalam Islam", terj.Nur Khozin (Jakarta: Amzah, 2001), hlm. 139.

${ }^{11}$ Sulaiman al-as'ats as-sijistany, Sunan Abu Dawud, (Beirut: Dar all-Kutub al'Ilmiyyah, 1996), hlm. 95.

12 Alfatih Suryadilaga, Aplikasi penelitian Hadits dari Teks ke Kontek (Yogyakarta: Kalimedia, 2016), hlm. 32. 
pernilai tsiqqah kecuali Sulaiman bin Musa yang kualitasnya shoduq, dan hal ini tidak merusak kualitas dari hadits ini. ${ }^{13}$ Dalam hadits lain dijelaskan melalui riwayat Imam Malik:

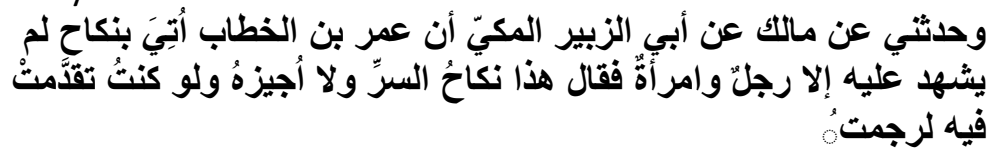

"Hal ini dipertegas dengan riwayat yang berasal dari Imam Malik: "Dari Abu Zubair al-Makki; Sesungguhnya Umar bin Khatab mendatangi sebuah pernikahan yang tidak disaksikan kecuali hanya kedua calon pengantin, maka Umar berkata, inilah pernikahan sirri dan aku tidak mengizinkannya, dan jikalau itu terjadi maka aku akan mengajukan kasus itu agar terkena hukum rajam".(HR. Malik). ${ }^{14}$

Kedua hadits tersebut secara mutlak menunjukkan perlawanan terhadap praktek nikah sirri. Meskipun al-Qur'an tidak menjelaskan hal tersebut, namun harus disadari bahwa hadits adalah penjelas dari al-Qur'an serta sumber kedua dari hukum-hukum Allah yang tidak ditemukan dalam alQur'an. Sebagai manusia yang beragama, mengetahui syari'at Tuhan adalah sesuatu yang penting, namun mengetahui hukum yang dibuat oleh manusia dalam tatanan negara juga suatu yang penting.

\section{Pernikahan Sirri dalam ranah ke-Indonesiaan}

Karena begitu pentingnya sebuah perkawinan di dalam Islam agar menuju kebaikan personal dan religius, maka di Indonesia perilaku ini mendapatkan perhatian yang tinggi hal ini dibuktikan dengan adanya UU No.1 Tahun 1974 yang membahas tentang perkawinan. Selanjutnya, dalam pasal 2 UU perkawinan, di sana dijelaskan. Pertama, perkawinan adalah sah, apabila dilakukan menurut hukum masing-masing agamanya dan kepercayaan itu; Kedua, tiap-tiap perkawinan dicatat menurut peraturan perundang-undangan yang berlaku.

Namun, setelah turunnya UU tersebut, kemdian muncullah dualisme antara kelompok tradisional dengan kelompok modern terkait syarat sah perkawinan. Permasalahan ini muncul ketika keluarnya fatwa Majlis Ulama' Indoneisa (MUI) yang membolehkan pernikahan sirri (tidak dilakukan di hadapan petugas pencatat nikah). ${ }^{15}$ Suatu hal yang menarik untuk dicermati,

${ }^{13}$ Takhrij Hadits melalui Jawami' al-Kalim Versi 4.5

14 Imam Malik, Muwatha' al-Malik biriwayati Yahya bin Yahya aal-Laitsy, (Beirut: Dar al-Kutub al-'Ilmiyyah, 2009), hlm. 281.

${ }^{15}$ Ahmad Rajafi, Nalar Hukum keluarga Islam Indonesia (Yogyakarta: Istana Publishing, 2015), hlm. 1523. 
bahwa ulama' membolehkan hal tersebut berdasarkan kesepakatan, tentu hal ini ada sebabnya, asumsi-asumsi mengenai hal ini akan dijelaskan dibelakang. Namun yang terpenting, pernikahan memang sudah selayaknya dicatatkan secara resmi pada instansi yang berwenang, sebagai langkah preventif untuk menolak dampak negative atau mudharat. ${ }^{16}$

Dalam perundang-undangan perwalian diatur dalam pasal 50.s.d 54 UUP.

1. Perwalian adalah kekuasaan seseorang sebagai wali terhadap seorang anak yang: a. Belum berusia 18 tahun, b. Belum pernah melangsungkan perkawinan, c. Tidak berada di bawah kekuasaan orang tua.

2. Syarat Wali (Pasal 51 ayat [1] dan [2] UUP): a. Diutamakan masih keluarga, b. Dewasa, c. Berpikir Sehat, d. Adil e. Jujur, f. Berkelakuan baik, g. Ditunjuk dengan surat oleh satu orang tua sebelum meninggal yang menjalankan kekuasaan orang tua, h. Penunjukan di hadapan dua orang saksi.

3. Tugas wali terhadap anak di bawah perwaliannya: a. Mengurusi pribadi dan harta benda anak dengan menghormati agama dan kepercayaannya, b. Membuat daftar harta benda anak, c. Mencatat perkembangan pribadi dan harta benda anak, d. Bertanggung jawab terhadap kerugian harta akibat kesalahan dan kelalaian wali, e. Tidak memindahkan hak atau menggadaikan harta benda anak tanpa untuk kepentingan anak.

4. Pencabutan kekuasaan wali:

a. Kekuasaan wali dapat dicabut, bila melalaikan kewajiban dan berkelakuan buruk.

b. Penunjukan pengganti wali yang dicabut ditetapkan oleh pengadilan. $^{17}$

Jadi masalah nikah sirri ini, juga harus dikaitkan dengan persoalan yang melikupi wali sebagai sosok yang menjadi pelindung dan pengatur sebagian urusan yang dibawah perwalian (mutawalli). Seseorang yang layak untuk menjadi wali bagi orang lain, maka sudah sewajarnya mentaati kewajiban sebagai wali dan bukan hanya mengambil keuntungan dari orang dibawah perwaliannya saja. Seperti orang tua yang menjodohkan anaknya hanya demi memperoleh harta dari menantu, tentu anak yang dibawah perwalian akan kesulitan untuk menolaknya dan memungkinkan seorang anak untuk melakukan nikah sirri. Meski hal ini bukan satu-satunya faktor, namun hal ini

${ }^{16}$ Seperti kawin lari dan ketidakjelasan pernikahan dalam tatanan kenegaraan.

17 Ladzi Safroni, Seluk-beluk Pernikahan Islam di Indonesia (Malang: Aditya Publishing, 2014), hlm. 135. 
selayaknya diperhatikan untuk mengentaskan permasalahan nikah sirri di masyarakat, yakni dengan mempertimbangkan masalah ke-sekufu'an.

\section{Hasil}

Ilmu antropologi secara umum menjelaskan perbedaan dan persamaan antara kebudayaan manusia yang tersebar di segala penjuru dunia, mencari titik temu dan solusi atas perubahan kebudayaan manusia, menjelaskan fenomena sosial budaya yang terjadi dalam kehidupan manusia dan menjelaskan perilaku manusia. ${ }^{18}$ Terkait hal tersebut, objek kajian antropologi dapat dibagi menjadi dua bidang, yaitu antropologi fisik yang mengkaji makhluk manusia sebagai organisme biologis, dan antropologi budaya. ${ }^{19}$

Secara umum perspektif antropologi menyangkut gejala sosial dan budaya. Dalam antropologi terdapat tiga macam perspektif besar dalam rangka melihat gejala sosial budaya yakni: Pertama, perspektif yang menekankan pada analisis masyarakat dan kebudayaan. Kedua, perspektif yang menekankan faktor waktu yang terdiri dari proses historis dari masa lampau sampai masa kini (diakronik), masa kini (sinkronik), dan interaksi masa lampau dan masa kini (interaksionis) dan Ketiga, perspektif konstelasi teori-teori, yakni penggabungan kedua perspektif. ${ }^{20}$

Salah satu masa peralihan terpenting dalam kehidupan manusia adalah peralihan dari masa remaja menuju masa dewasa dan berkeluarga yang ditandai dengan perkawinan. Dan hal ini memperoleh perhatian yang lebih dari para antropolog. Dalam terminologi antropologi, terdapat perbedaan antara upacara perkawinan yang dilakukan di bawah naungan agama dan perkawinan sipil yang diberi kebenaran oleh negara. Namun, tidak dipungkiri bahwa dibeberapa negara tidak memisahkan kedua ritual ini, seperti di Amerika. ${ }^{21}$ Di Indonesia sendiri, termasuk penganut paham yang memisahkan dua unsur ini, maka tentu sudah sewajarnya melihat kemaslahatan yang dibawa dalam undang-undang pernikahan yang termasuk di dalamnya mencatatkan pernikahan maka mengikuti aturan negara dan meninggalkan nikah sirri adalah muthlak harus diikuti. Selain itu, disadari maupun tidak bahwa nikah sirri sebenarnya hanya dimaknai sebagai legalisasi prostitusi yang secara tidak langsung dibutuhkan tindakan untuk mengatasinya.

\footnotetext{
${ }^{18}$ Nur Syam, Mazhab-mazhab Antropologi (Yogyakarta: LKIS, 2007), hlm, 30.

${ }^{19}$ Koentjayaningrat, Pengantar Ilmu Antropologi (Jakarta: Rineka Cipta, 1990), hlm.11.

${ }^{20}$ Alfatih Suryadilaga, "Pembacaan Hadits Dalam Perspektif Antropologi", AlQalam, Banten, Vol 31, No. 1 Januari-Juni 2014, hlm.4

21 Sugeng Pujileksono, Pengantar Antropologi (Malang: UMM Press, 2009), hlm, 32.
} 
Hadits nikah sirri dalam perspektif antropologi maka tidak bisa lepas dari diri Nabi Muhammad saw. namun sebelumnya harus diteliti lebih dahulu apakah hadits pelarangan nikah sirri-nikah tanpa wali dan tanpa diumumkan-benar-benar dari Nabi muhammad saw. atau tidak. Jika dilihat dari riwayat di atas sudah jelas bahwa pernikahan sirri pada saat masa sahabat Umar ada, dan hal ini dilarang.

Dalam konteks kekinian, kita masih mendapati orang melangsungkan pernikahan yang syarat dan rukunnya terpenuhi tanpa mencatatkan pernikahan itu secara resmi kepada pihak yang berwenang, memang pernikahan seperti ini hukumnya sah secara agama sehingga mengharuskan pasangan suami-istri untuk saling memenuhi hak dan kewajiban masingmasing. Namun, tentu pernikahan seperti ini tidak diakui secara undangundangan dalam pengertian bahwa pernikahan itu tidak bisa dibuktikan di hadapan pihak berwenang kecuali dengan data dan catatan resmi. ${ }^{22}$

Jika demikian, maka seseorang yang melakukan nikah sirri sebenarnya tidak mematuhi tata aturan yang telah ditetapkan oleh pemerintah. Satu sisi orang mencoba melegitimasi pernikahan sirri namun di sisi lain menentang peraturan pemerintah. Padahal agama telah menganjurkan manusia untuk mentaati peraturan negara, seperti dalam firman Allah:

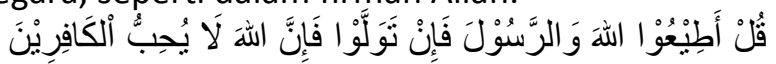

"Hai orang-orang yang beriman, taatilah Allah dan taatilah

Rasul-Nya, dan ulil amri di antara kamu".

Memang tidak selamanya perintah itu harus diikuti, karena perintah di sini dimaksudkan hanya perintah yang baik-baik saja, jika hal ini disignifikansikan dalam ranah perintah pencatatan dan adanya perwalian maka sebenarnya perintah ini termasuk dalam makna ayat di atas.

Tentu dengan adanya hal tersebut akan menutup mudharat dari nikah sirri, karena bisa jadi seorang suami mengingkari pernikahannya dengan istrinya. Seorang istri juga tidak akan bisa mengajukan bukti-bukti yang menunjukkan bahwa mereka adalah sepasang suami istri. Dan bisa juga seorang istri menikah dengan pria lain secara resmi dalam situasinya yang masih terikat dengan hubungan dengan suami pertama yang menikahinya secara bawah tangan. Seorang suami bisa pula menggantung nasib istrinya dan mendiamkannya tanpa dicerai sehingga secara agama-pun sang istri tak akan bisa menikah dengan pria lain. Dan mungkin juga jika salah satu pihak meninggal dunia, ahli waris mereka bias saja tidak mengakui keikutsertaan

${ }^{22}$ Sayyid Ahmad al-Musayyar, Fiqih Cinta Kasih, Ed. Taqyudin dan Yahya (Jakarta: Erlangga, 2008), hlm. 141. 
pihak yang ditinggal mati dalam perolehan warisan, karena tidak ada bukti pendukung yang resmi secara undunag-undang. ${ }^{23}$

Dalam memaknai ajaran Islam yang terpenting adalah melihat tujuan perintah tersebut, adapun tujuan pernikahan diantaranya:

1. Melanjutkan keturunan

Seperti sabda Nabi:

$$
\text { تزوجوا الودود الولود فإني مكاثربكم الأنبياء يوم القيامة (رواه أحمد وابن حبان) }
$$

2. Untuk menjaga diri dari perbuatan-perbuatan yang dilarang Allah mengerjakannya, sesuai dengan hadits:

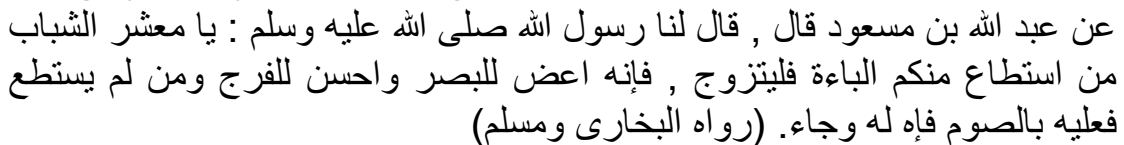

3. Untuk menimbulkan rasa cinta antara suami dan istri, menimbukan rasa kasih sayang antara orang tua dengan anak-anaknya dan adanya rasa kasih sayang antara sesama anggota keluarga.

4. Untuk menghormati sunnah Rasulullah saw.

5. Untuk membersihkan keturunan, yakni keturunan yang bersih, yang jelas ayah, kakek dan sebagainya, dan hal ini dapat diperoleh dengan perkawinan yang mencatatkan pernikahan. ${ }^{24}$

Dari sekian banyak mudhrat yang bisa ditimbulkan dari nikah sirri tentu hal ini secara pasti menunjukkan perintah untuk mengikuti Ulil 'Amri terkait masalah pernikahan. Dari penjelasan di atas sudah sangat jelas bahwa hadits tentang pelarangan nikah sirri sudah dimanifestasikan dalam undang-undang kenegaraan, namun masih saja ditemukan kasus nikah sirri di berbagai kalangan masyarakat, hal ini jika dilihat dari sisi antropologi memunculkan beberapa pandangan yang melatarelakangi kasus tersebut:

1. Ketidaksetujuan wali.

2. Hilangnya fungsi sekufu (seimbang antara kedua pihak) dalam pernikahan.

3. Kebutuhan biologis manusia semakin bertambah.

Dalam sensus yang dilakukan oleh Lembaga Swadaya Masyarakat (LSM) Pemberdayaan Perempuan Kepala Keluarga (Pekka), 25 persen masyarakat di Indonesia melakukan kawin sirri dan nikah secara adat pada tahun 2012. Artinya pernikahan ini tidak tercatat di negara. Sementara hasil penelitian dari Badan Litbang dan Diklat Kementerian Agama di sembilan

${ }^{23}$ Sayyid Ahmad al-Musayyar, Fiqih Cinta Kasih ... hlm, 142.

24 Kamal Mukhtar, Asas-asas Hukum Islam tentang Perkawinan, (Bulan Bintang, 1993), hlm. 13-14. 
kabupaten di Indonesia, banyak orang melakukan nikah sirri dan perkawinan di bawah umur karena stigma masyarakat akan status perawan tua. ${ }^{25}$

Dari fakta tersebut sebenarnya dapat ditemukan suatu kesenjangan yang nyata antara undang-undang yang berbasis kenegaraan dengan praktek masyarakat yang menjadikan teks keagamaan sebagai sebab pelegitimasian praktek nikah sirri. Maka permasalahannya jelas, apakah teks keagamaan yang dirubah atau undang-undang kenegaraan yang dirubah. Karena dalam perundang-undangan hanya dibatasi oleh dua persyaratan yakni hukum masing-masing agamanya dan kepercayaan itu, dan kewajiban untuk mencatatkan menurut peraturan perundang-undangan yang berlaku. ${ }^{26}$

Dalam perpektif antropologi, sebagian besar perilaku manusia dalam kehidupan sosialnya merupakan hasil dari proses belajar. Perilaku dan kebiasaannya bukanlah merupakan hasil pewarisan secara genetic, tetapi merupakan pembawaan yang diturunkan secara sosial (Social Heredity). ${ }^{27}$ Oleh karena itu, pernikahan sirri yang dipahami oleh masyarakat, tidak bisa dilepaskan dari pelaku nikah sirri yang dipraktekkan oleh orang yang paham dengan agama (tata aturan nikah dalam Islam), dan hal ini akan memunculkan asumsi baru bahwa orang paham agama Islam (Baca: paham adanya praktek nikah sirri dalam Islam) akan lebih rentan melakukan pernikahan sirri.

Namun, dari sisi antropologi, tidak selamanya nikah sirri itu dilarang, karena terkadang nikah sirri itu dapat menjadi titik temu terselesaikannya masalah moral manusia, seperti perzinaan, pacaran dsj. Terkadang seseorang yang belum mampu melakukan nikah secara resmi, dalam artian mempunyai uang yang banyak untuk melangsungkan acara pernikahan, akan membuka peluang untuk melakukan kemaksiatan-kemaksiatan.

Di sisi lain, ditemukan orang tua yang menjodohkan anaknya hanya sebatas karena faktor materiil dan tanpa melihat kesekufu'an, hal ini juga bisa menghalangi kemamuan anak untuk melakukan pernikahan yang sesuai dengan peraturan yang berlaku atau bahkan sebaliknya, seperti kasus'pencabulan' yang dilakukan anggota DPRD Kab. Sampang yang melakukan nikah sirri instan di mobil sambil memberikan uang "nafkan" Rp. 2 juta. ${ }^{28}$ Maka, dalam persoalan seperti ini, hukum nikah sirri bisa bersifat

25 "25 persen masyarakat Indonesia melakukan nikah sirih" diakses dari //www.merdeka.com/peristiwa/25-persen-masyarakat-indonesia-melakukan-nikahsiri.html, pada tannggal 11 Desember 2017 pukul 09.00.

${ }^{26}$ Ahmad Rajafi, Nalar Hukum keluarga ... hlm. 152.

${ }^{27}$ Sugeng Pujileksono, Pengantar Antropologi ... hlm. 17.

28 Alfatih Suryadilaga, Nikah Sirri dalam Perbincangan Media Massa ... hlm.109. 
fleksibel, terkadang hal ini hanya dijadikan pemuas hawa nafsu, di sisi lain sebagai cara untuk mengatasi masalah perekonomian terkait perayaan bagi orang yang menikah. Nilai terpenting di sini, bahwa nikah sirri itu harus dicatatkan baik dengan perayaan atau tidak dan bukan dlakukan sebagai bentuk pelegalan prostitusi berdasarkan agama yang dipahami secara salah.

\section{Penutup}

Nikah sirri adalah nikah yang tidak dihadiri oleh saksi, baik dalam ranah keagamaan dan perundang-undangan kenegaraan hal ini tidak dibolehkan. Dari sisi antropologis pernikahan sirri yang terjadi bisa disebabkan karena pengambilan kebudayaan yang terjadi di masa lampau, tanpa melihat sisi sosio-historis yang melikupinya.

Pernikahan sirri juga sebenarnya bisa dikaitkan dengan masalah ketidak setujuan wali, kurangnya perekonomian, dan bahkan tercukupinya perekonomian seseorang dapat menyebabkan terjadinya nikah sirri, terkait hal ini penyebab kedua dapat dijadikan alasan pelegalan seseorang melakukan pernikahan sirri, jika dalam artian nikah sirri ini tetap dicatatkan namun tanpa adanya perayaan yang mewah dan ramai.

\section{Daftar Rujukan}

Alfatih Suryadilaga, Muhammad, "Syarah Hadits Shahih Bukhari dan Muslim dalam Komik", Esensia, Vol. 16, No. 2, Oktober. 2015.

Alfatih Suryadilaga, Muhammad, Aplikasi penelitian Hadits dari Teks ke Konteks, Yogyakarta: Kalimedia, 2016.

Alfatih Suryadilaga, Muhammad, Metodologi Syarah Hadits, Yogyakarta: Kalimedia, 2017.

Alfatih Suryadilaga, Muhammad, "Nikah Sirri dalam Perbincangan Media Massa", Musawa, Vol 12 No. 1 Januari 2013.

Alfatih Suryadilaga, Muhammad, Aplikasi penelitian Hadits dari Teks ke Konteks, Yogyakarta: Kalimedia, 2016.

Alfatih Suryadilaga, Muhammad, "Pembacaan Hadits Dalam Perspektif Antropologi dalam Al-Qalam", Banten, Vol 31, No. 1 Januari-Juni 2014.

https://www.merdeka.com/peristiwa/25-persen-masyarakat-indonesiamelakukan-nikah-siri.html

Imam Malik, Muwatha' al-Malik biriwayati Yahya bin Yahya aal-Laitsy. Beirut: Dar al-Kutub al-'Ilmiyyah, 2009. 
Jawami' al-Kalim Versi 4.5

Koentjayaningrat, Pengantar IImu Antropologi, Jakarta: Rineka Cipta, 1990.

Mukhtar, Kamal, Asas-asas Hukum Islam tentang Perkawinan, Bandung: Bulan Bintang, 1993.

Munawwir, A. W, Kamus al-Muanawwir Arab Indonesia Terlengkap, Surabaya: Pustaka Progressif, 1997.

Musayyar, Sayyid Ahmad, Fiqih Cinta Kasih, Ed. Taqyudin dan Yahya, Jakarta: Erlangga, 2008.

Pujileksono, Sugeng, Pengantar Antropologi, Malang: UMM Press, 2009.

Qardhawi, Yusuf, Bagaimana Memahami Hadits Nabi saw.,terj. Muhammad al-Baqir, Bandung: Mizan, 1997.

Rajafi, Ahmad, Nalar Hukum keluarga Islam Indonesia, Yogyakarta: Istana Publishing, 2015.

Safroni, Ladzi, Seluk-beluk Pernikahan Islam di Indonesia, Malang: Aditya Publishing, 2014.

Sijistany, Sulaiman al-as'ats, Sunan Abu Dawud, Beirut: Dar all-Kutub al'Ilmiyyah, 1996.

Subki, Ali Yusuf, Fikih Keluarga pedoman berkeluarga dalam Islam, terj.Nur Khozin. Jakarta: Amzah, 2001.

Syam, Nur, Mazhab-mazhab Antropologi, Yogyakarta: LKIS, 2007. 